whether from that of education, the investigations which lead up to the planning, or the technical aspects and administrative detail of the planning itself, the responsibilities and opportunities of scientific workers are unmistakable. If we are to build, with resources impaired if not crippled by the sacrifices and vicissitudes of wartime, a social order in which the advantages which modern science has put at our disposal are more freely and fully utilized, and the present obstacles to that utilization or the forces dissipating our resources have been eliminated, scientific workers must play a major part. No defeatist spirit can be tolerated.
Only as men and women, whether scientific workers or not, address themselves hopefully and adventurously to this creative task, ready to seize whatever opportunities may come and resolved that no inherited prejudices or vested interests of administration or property shall be allowed to injure the common welfare, can we hope to build cities and communities which will enjoy the true abundance which might be ours. We must be planning for that future even in the stress of war, if we are to be ready when the opportunity comes to transmute our dreams and visions into the cities, workshops and homes of a new era of civilization.

\title{
FUTURE OF ZOOLOGY IN INDIA
}

$\mathrm{A}^{\mathrm{I}}$ LONG series of volumes, bearing the title of "The Fauna of British India", has been published under the authority of the Secretary of State for India, with the object of ensuring that the rich fauna of that great continental area is made properly known and, at the same time, of providing authoritative means for its identification. While its inception is more than fifty years old, the wisdom in launching this project has become increasingly justified in recent years. The first volume, which dealt with part of the Mammalia, appeared in 1888 . The latest volume, also dealing with Mammalia, was issued in 1939 and is reviewed on the next page. Throughout this period, one or more volumes have been issued almost every year. During the War of 1914-1918, five volumes were published.

The "Fauna of India" has become increasingly used in Indian universities, colleges and museums. Furthermore, certain of the volumes rank as essential tools in the work of the scientific staffs of those Government departments concerned with agriculture, fisheries, forestry and tropical medicine; and indeed, certain forthcoming volumes promise to be of special importance in this respect. The "Fauna" series aims at providing accurate descriptions of all species of Indian animals and, thereby, forms the basis upon which further study depends. The importance of accurate identification scarcely needs stressing, whether it be, for example, of a mosquito concerned with disease transmission, an insect devouring a crop or an animal of solely scientific interest.

This primary object of the "Fauna" is being gradually achieved, but there is still a long and uphill road to traverse. For one thing, some of the earlier volumes are now out of date and need revision in the light of increased knowledge. Many divisions of the animal kingdom have not yet been dealt with, and there is the added difficulty of finding competent specialists willing to undertake the monographing of certain important groups. The Termites are a case in point, as they rank among the most destructive of Indian insects; little progress is being made in their study, mainly owing to difficulties attending their identification.

We learn with regret that the Secretary of State for India has decided to cease publication of the "Fauna of British India" for the duration of the War. While recognizing the present necessity for economy, it needs emphasizing that much of zoological progress in India may become involved in this decision. It behoves those who have such progress at heart to combine their efforts and do all that is possible to discourage any policy directed towards further economy, possibly resulting in the cessation of the publication of the "Fauna of India" altogether. Such an outcome would, in the long run, heavily counterbalance any monetary savings achieved.

The projected dominion status for India is linked with the growing part being played by Indians in the scientific development of their country. In this latter connexion they need every help that we can provide. From the zoological point of view, the least we can do is to ensure the continuance of this long-established publication. 